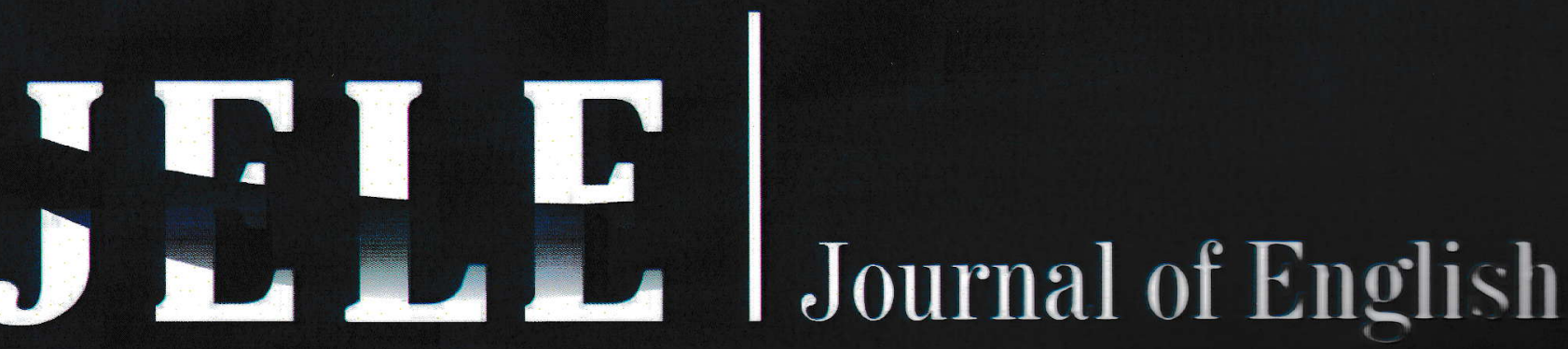 Language and Education
}

English Education Study Program Faculty of Teachers Training and Education Mercu Buana University of Yogyakarta 


\title{
The Effectiveness of Process Genre and Product Genre Approaches to Teach Writing to Introvert and Extrovert Students (The Case of the Tenth Year Students of State Senior High School 1 Wirosari-Grobogan in the Academic Year of 2013/2014)
}

\author{
Wahyu Kyestiati Sumarno \\ English Education Department, Faculty of Post Graduate Program \\ State University of Semarang \\ Email : kyestiatisumarno@yahoo.com
}

\begin{abstract}
This present study aims to investigate the effectiveness of Process Genre and Product Genre Approaches to teach writing to introvert and extrovert students. A quasi-experimental study with $2 \times 2$ factorial designs was conducted to gain answers. Data were collected by using Myers Briggs Type Indicator, observation notes and a pre-and-posttest. Data were analyzed by using T-test, Two-Way Anova, and Tukey test. The findings revealed that first, Process Genre Approach was significantly effective to be used to teach writing to both the introvert and extrovert students; while, the Product Genre Approach was only effective to be used to teach writing to the extrovert students. Second, quantitatively, the Process Genre Approach was not significantly more effective to be used to teach writing compared to the Product Genre Approach. Third, the students' personalities significantly influenced their writing quality, in which the extrovert students' writings were better than the introvert students' writings. Fourth, there was a significant interaction occurred between the teaching approaches and the students' personalities on their writing quality. Based on the study results, the researcher suggests English teachers to consider using Process Genre Approach in their writing classes and identify each student's personality in the very beginning of lessons, acknowledging that the students' personalities significantly influence the students' writing quality.
\end{abstract}

Keywords: Process Genre Approach; Student's Personality; Writing Instruction

\section{INTRODUCTION}

Writing instruction has become

a field of increasing interest at higher learning institutions in recent years. After a long ignorance, people are now finding ways to effectively teach the skill which is considered as one of the most difficult skills needs to be mastered by second language learners. Writing requires its learners to have a certain amount of L2 background knowledge before they are ready to start drafting in order to communicate with their readers. Hence, quite a long journey of learning is necessary to make the learners prepared. 
In Indonesia, in spite of its major role in academic setting, the instruction of writing skills remains ineffective. The Product Genre Approach, which is widely used at most Indonesian senior high school classrooms, focus mostly on the students' single-draft writing products that emphasize on the grammatical and linguistic correction only rather than the students' writing skills development and process writing practices. These tendencies result in the students' lack of writing practices that lead to the production of students with low quality of writing.

To overcome this problem, in this study, the writer tried to compare the effectiveness two approaches, namely, Product Genre approach and Process Genre approach.

Product Genre Approach in this study refers to the Genre-based Approach, which is argued as the extension of product approach and is criticized undervalues the skills needed to produce a text, e.g. drafting, revising, editing, etc. (Badger and White, 2000: 157). As in Product Approach, the Genre-based Approach views writing as predominantly linguistic. However, Genre-based
Approach places a greater emphasis on the social context in which writing is produced. This approach essentially concerned with the knowledge of language and as being tied closely to a social purpose (Badger and White, 2000: 153). This approach views learning to write activities as the analysis and imitation of input in the form of texts provided by the teachers.

Meanwhile, Process Genre Approach is defined as an approach that primarily concerned with the knowledge about language, knowledge of the context in which writing happens, especially the purpose of writing, and the skills in using language (Badger and White, 2000: 157). This approach sees learning to write as drawing out the learners' potential by providing input to which the learners respond (Badger and White, 2000: 158). Process Genre Approach is a synthesis approach which incorporates the insights of Product, Process, and Genre-based Approach proposed by some researchers including Badger and White (2000) and Tangpermpoon (2008).

A number of research studies related to the implementation of 
Process Approach, Genre-based Approach, and Process Genre Approach in the teaching of writing have been conducted in numerous classrooms in different part of the world. Some of those studies noted that Process Approach was significantly effective to be used to help students improving their writing quality (Parks, et. al., 2005; Ho, 2006). Yet, Graham and Sandmel (2011) found in their study that process writing instruction resulted in a statistically significant, but relatively modest improvement in overall students' quality of writing. They also noted that the process writing approach neither resulted in a statistically significant improvement in students' motivation nor enhanced the quality of struggling writers' composition.

Similar to the above findings, some researchers also found in their studies that Genre-based Approach was effective to be used to teach writing (Amogne, 2013; Chen and Su, 2012), but Yang's (2012) study indicated that quantitatively, Genrebased writing instruction seemingly did not adequately help students in reaching the instructional aims.
Meanwhile, Gupitasari (2013) reported her study on the implementation of the Process Genre Approach to teaching writing business letters. The results demonstrated improvement in students' writing ability, evidenced in the increase in scores obtained at the end of the teaching program. The results of the questionnaire also showed the students' consciousness that Process Genre approach could help improve their writing ability, especially writing application letters.

Furthermore, in line with Brown (2000: 142) who argues that personality is one of the affective factors that are equally important for explaining differential success among second language learners, the writer then assumes that students' personalities have an important role in influencing the students' learning outcomes, specifically on their quality of writing.

Previous research suggests that introvert learners tend to be quiet and prefer non-social activities (Ellis, 1994: 518); while, extrovert learners tend to be sociable, risk-taking, lively, and active (Ellis, 1994: 518). These distinctive characteristics assumed by 
the writer will be an important factor which will give different effects on the students' writing achievement, particularly if they are taught by using Process Genre Approach. Process Genre Approach covers steps in writing process, including drafting, revising, and editing, which are done in pairs as well as in group discussions. These pair and group works will probably discomfort the introvert students but fortunate the extroverts. During the feedback stages, the extrovert learners may learn by actively give their opinions while the introvert learners may think and reflect more when they read their friends' feedback. During the pair and group works, it may occur that extrovert learners are motivated by the introvert learners' analytical and thoughtful discussions, while, conversely, introvert learners will be inspired by the extrovert learners' spontaneous feedbacks and fresh ideas.

Finally, in order to discover the influence of students' personalities on their writing quality and the effectiveness of Process Genre and Product Genre Approaches, this study was conducted by the writer. It is hoped that this investigation can shed light on researching and teaching English writing courses in EFL settings.

\section{METHODS}

This research is a quasi experimental study with $2 \times 2$ factorial designs. The writer investigated the effectiveness and interaction that occurred by the application of Product Genre Approach and Process Genre Approach to writing lessons while also giving attention to the influence of students' personalities (introvert and extrovert) on their writing quality. The pre-test post-test with control group design was used in this study. Table 1 illustrates the design of research the researcher had conducted.

This study was conducted in an institution whose regulation is implemented. It resulted in some limitations to the side of the researcher, which made her applied purposive sampling technique to get the study's samples. Purposive sampling technique is defined as the technique of samples taking which consider a certain consideration (Sugiyono, 2011: 68). In this case, the 
consideration refers to the school constraint.

The population of this study was the tenth year students of State Senior High School 1 WirosariGrobogan in the academic year of 2013/2014. There were eight classes, with different amount of students in each class. The samples (two classes only) were taken from those classes chosen by using purposive sampling technique. The first class was treated as the experimental class that received Process Genre Approach, while the other class was the control class that was taught by using Product Genre Approach.

The instruments used in this study were Observation Notes, Myers Briggs Type Indicator (MBTI), and Pre-and-Post-test.

Table 1. Research Design

(Cohen, Manion, and Morrison, 2007: 280)

\begin{tabular}{|c|c|c|c|c|}
\hline $\begin{array}{l}\text { Writing } \\
\text { Approaches } \\
\text { Personts' } \\
\text { Persalities }\end{array}$ & $\begin{array}{l}\text { Process Genre } \\
\text { Approach } \\
\text { (Experiment } \\
\text { Group) } \\
\text { (X1) }\end{array}$ & $\begin{array}{l}\text { Product Genre } \\
\text { Approach } \\
\text { (Control } \\
\text { Group) } \\
\text { (X2) }\end{array}$ & & \\
\hline \multirow[t]{2}{*}{ Introvert (Y1) } & $\mathrm{X} 1 \mathrm{Y} 1$ & $\mathrm{X} 2 \mathrm{Y} 1$ & $\mathrm{X} 1 \mathrm{X} 2 \mathrm{Y} 1$ & \\
\hline & (Question 1) & (Question 3) & & (Question 6) \\
\hline \multirow[t]{4}{*}{ Extrovert (Y2) } & $\mathrm{X} 1 \mathrm{Y} 2$ & $\mathrm{X} 2 \mathrm{Y} 2$ & $\mathrm{X} 1 \mathrm{X} 2 \mathrm{Y} 2$ & \\
\hline & (Question 2) & (Question 4) & & \\
\hline & $\mathrm{X} 1 \mathrm{Y} 1 \mathrm{Y} 2$ & $\mathrm{X} 2 \mathrm{Y} 1 \mathrm{Y} 2$ & & \\
\hline & \multicolumn{2}{|c|}{ (Question 5) } & & \\
\hline
\end{tabular}




\section{FINDINGS AND DISCUSSION}

To obtain the data, the researcher did a number of procedures. First, to find out the students' personalities, the researcher had the students fill an adapted-translated Myers Briggs Type Indicator (MBTI) scale designed by Nafis Mudrika (2011), referring to the original version developed by Katherine Briggs and Isabel Briggs Myers (1962). For the purpose of rechecking the data, the researcher also did observations and asked the classroom teacher as well as all the classmates to share their opinions about their friends' personalities. Among seventy students in control and experimental groups (35 students each), the researcher took ten introvert and ten extrovert students from each group.

After capturing the students' personalities, the researcher conducted pre-test to identify the students' prior knowledge, and then followed by the three meetings of treatments (2X45 minutes for each meeting). Post-test was given in the end of the treatments to examine if there were improvements of the students' writing quality after sequence of treatments given. Table 2 shows the students' scores of pre-test and post-test which were analyzed to answer the research questions.

The scores on table 2indicated that all the mean scores of the groups were increased from the pre-test to the post-test. The introvert students' mean score taught by using Process Genre Approach was increased from 68.5 to 82.7; and from 66.1 to 71.6 when taught using the Product Genre Approach. Meanwhile, the extrovert students' mean score taught by using Process Genre Approach was improved from 69.4 to 82.9 ; and from 72.7 to 84.2 when taught using the Product Genre Approach.

To analyze the findings systematically, the writer divided this subtopic into seven points based on the research questions as follows.

First, the effectiveness of Process Genre Approach used to teach writing to introvert students. The significant value ( $p$ value) got from the T-test was $0.002=0.2 \%<5 \%$. Since the $p$ value $<\alpha$ (standard error), so it means that the Process Genre Approach was significantly effective to be used to teach writing to the introvert students. 
Second, the effectiveness of Process Genre Approach used to teach writing to extrovert Students. The significant value $(p)$ got from the Ttest was $0.001=0.1 \%<5 \%$. Since the $p$ value $<\alpha$ (standard error), so it means that the Process Genre Approach was significantly effective to be used to teach writing to the extrovert students.

Third, the effectiveness of Product Genre Approach used to teach writing to introvert students. The significant value $(p)$ got from the Ttest was $0.306=30.6 \%>5 \%$. Since the $p$ value $>\alpha$ (standard error), so it means that the Product Genre Approach was not significantly effective to be used to teach writing to the introvert students.

Fourth, the effectiveness of Product Genre Approach used to teach writing to extrovert students. The significant value got from the T-test was $0.005=0.5 \%<5 \%$. Since the $p$ value $<\alpha$ (standard error), so it means that the Product Genre Approach was significantly effective to be used to teach writing to the extrovert students.

Fifth, the significant difference of the two writing approaches when used to teach writing. The test of two- way ANOVA ascertained that the two approaches had no significant difference if the standard error $(\alpha)$ were $5 \%$ and $10 \%, p$ value $=0.106=$ $10.6>0.05 ; 10.6>0.1$. This resultmeant that although there were differences in the achievements of students taught by using the Process Genre and Product Genre Approaches, in which students in Process Genre Approach class got higher group mean (82.8) rather than students in Product Genre Approach class (77.9), but based on the Two Way Anova test, the difference was not significant.

Based on that finding, Process Genre Approach seemingly did not adequately help the students reaching significant higher writing scores. However, it is essential to bear in mind that the students were only given three meetings (90 minutes each) to get involve with the approach which contains some stages. It might have been an insufficient amount of time for students to enjoy the process and to make adequate revisions. Furthermore, this was the first time that these students were taught by using Process Genre Approach. The unfamiliarity with the teaching method might have influenced their 
performance. The brainstorming stage, the self - peer checklist, and the revision stages seemed to be challenging for its newness.

In this case, the writer argues that focusing exclusively on the quantitative results may not adequately capture the complexities involved in conducting this approach. Even though there was no significant difference between the two approaches, but the difference of the mean scores, in which the Process Genre Approach class gained higher mean scores, had simply indicated that this approach helped the students improve their writing quality. This could also be seen from the qualitative analysis of the students' writings, in which the organizations of the text of the students' writings were getting better, together with the content, grammar and punctuation. Although the students in Product Genre Approach class also showed their improvements, yet the average achievement of the Process Genre Approach class was higher. Even, few students in the Product Genre Approach class got worse results than before. Furthermore, the style and expression of the students in Process
Genre Approach class seemed more varied than the students in Product Genre Approach class.

Sixth is regarding the influence of the students' personalities (introvert and extrovert) on their writing quality if they were taught by using the two approaches. The test of two-way ANOVA indicated that there was a significant influence of students' personalities on their writing quality, $p$ value $=0.037<0.05$. In other words, based on this study, the students' personalities, in this case introvert and extrovert, influenced the quality of their writing. The extrovert students got generally higher scores (mean score: 83.55$)$ compared to the introvert students (mean score: 77.15). It meant that extrovert students tended to get higher results than the introvert students. This is in line with the study of Qomarudin (2010) who found a positive correlation between extroversion and English writing skill. Seventh is regarding the interaction between the writing approaches (process genre and product genre approaches) and the students' personalities on their writing quality. The test of two-way ANOVA showed that there was an interaction occurred 
between the writing approaches and the students' personalities on the students' writing quality, $p$ value $=0.043<0.05 ;$ in which extrovert students got higher scores when they were taught by using Product Genre Approach, while the introvert students got higher achievements when they were taught using Process Genre Approach. There was a meeting point between the two lines (introvert and extrovert) showed in graph 1 of the Two-Way Anova which clarified the interaction.

\section{Graph1. Interactions between the Writing Approaches and the Students' Personalities}

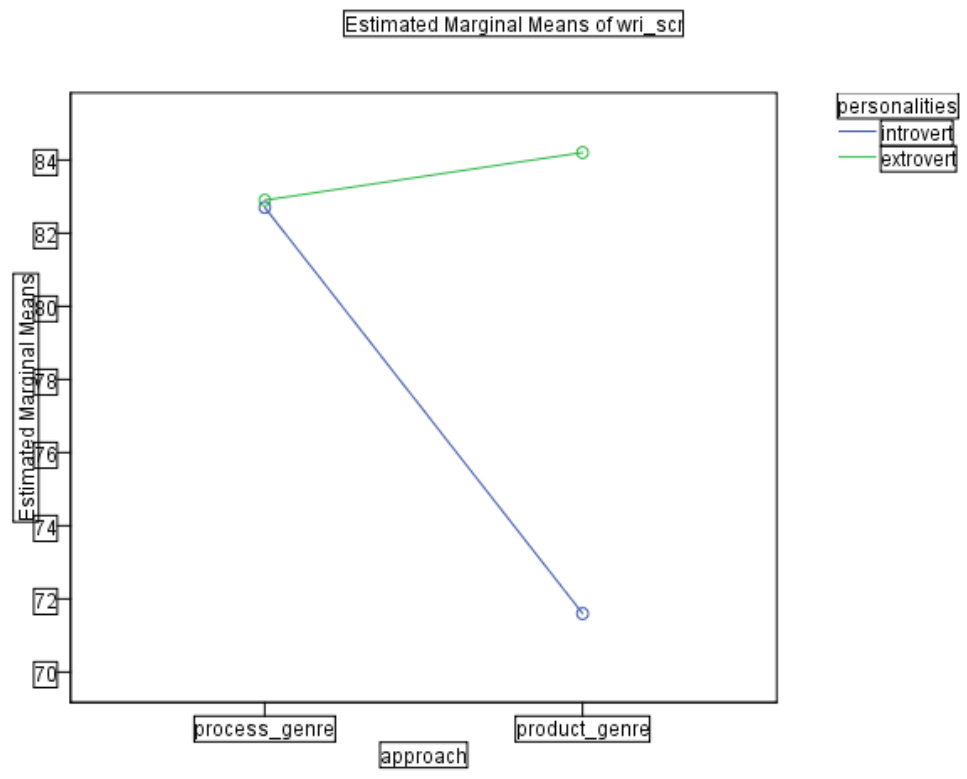

These findings were actually were taught by using Product Genre different to what had been predicted Approach. Some reasons that might previously. Introvert students which cause these results were the tendency were predicted would get some of the introvert students to be troubles when taught by using Process reflective thinkers and thoughtful. Genre Approach since there were Hence, they were more serious to some interactions during the learning learn the materials given, even when process, surprisingly showed their the materials were given with a new significant improvement instead. On approach. Numerous steps in Process the contrary, the extrovert students Genre Approach including the self and showed their better scores when they peer checklists to get some feedbacks 
and the revision stages, had made the introvert students got into deeper understanding and reflections. They were mostly responsive and diligent students that willingly do their homework. Their revisions and final drafts were better than before.

Meanwhile, the extrovert students seemed less serious to do some steps in Process Genre Approach. It was agreed with their tendency to have fewer thoughts and less reflective even during the revision stages. Most of them were reluctantly did their task well. Revision steps seemed does not quite help them to get better understanding. They tended to feel more comfortable with simpler procedures as in Product Genre
Approach rather than approach with many steps as in the Process Genre Approach.

To examine the significance of the interaction between the groups, post hoc test using Tukey Test was done. This test indicated that extrovert students who were taught using Process Genre Approach got significantly higher results than the introvert students taught by using Product Genre Approach. Also extrovert students who were taught using Product Genre Approach got significant higher results than the introvert students taught by using Product Genre Approach. The other groups might have differences but were not significant. 
Table 2. The Students' Pre-and-Post-Test Scores

\begin{tabular}{ccccccc}
\hline & \multicolumn{2}{c}{ Process Genre Approach } & \multicolumn{3}{c}{ Product Genre Approach } \\
\cline { 2 - 7 } $\begin{array}{c}\text { Students' } \\
\text { Code }\end{array}$ & $\begin{array}{c}\text { Pre- } \\
\text { test }\end{array}$ & $\begin{array}{c}\text { Post- } \\
\text { post }\end{array}$ & $\begin{array}{c}\text { Students } \\
\text {, Code }\end{array}$ & Pre-test & Post-test \\
\hline Introvert & ES-1 & 69 & 94 & CS-1 & 72 & 97 \\
& ES-2 & 76 & 96 & CS-2 & 55 & 75 \\
ES-3 & 58 & 80 & CS-3 & 77 & 87 \\
ES-4 & 72 & 77 & CS-4 & 75 & 60 \\
ES-5 & 74 & 84 & CS-5 & 76 & 56 \\
ES-6 & 82 & 92 & CS-6 & 55 & 60 \\
ES-7 & 74 & 79 & CS-7 & 63 & 53 \\
ES-8 & 55 & 70 & CS-8 & 60 & 75 \\
ES-9 & 61 & 76 & CS-9 & 62 & 77 \\
ES-10 & 64 & 79 & CS-10 & 66 & 76 \\
\hline Mean & $\mathbf{6 8 . 5}$ & $\mathbf{8 2 . 7}$ & Mean & $\mathbf{6 6 . 1}$ & $\mathbf{7 1 . 6}$ \\
& & & & & \\
\hline & & 86 & CS-11 & 63 & 83 \\
ES-11 & 61 & 86 & CS-12 & 70 & 85 \\
ES-12 & 74 & 84 & CS-13 & 77 & 87 \\
ES-13 & 78 & 88 & CS-14 & 68 & 88 \\
ES-14 & 82 & 92 & CS-15 & 55 & 90 \\
ES-15 & 76 & 91 & CS-16 & 85 & 75 \\
ES-16 & 56 & 76 & CS-17 & 78 & 83 \\
ES-17 & 60 & 80 & CS-18 & 80 & 75 \\
ES-18 & 73 & 78 & CS-18 & 94 \\
ES-19 & 64 & 79 & CS-19 & 84 & 82 \\
ES-20 & 70 & 75 & CS-20 & 67 & $\mathbf{8 4 . 2}$ \\
\hline & $\mathbf{6 9 . 4}$ & $\mathbf{8 2 . 9}$ & Mean & $\mathbf{7 2 . 7}$ & & \\
\hline
\end{tabular}

\section{CONCLUSION}

Based on the findings of the research conducted to the tenth graders of State Senior High School 1 Wirosari-Grobogan, the following conclusions could be drawn.

First, that the Process Genre Approach was significantly effective to be used to teach writing to introvert students. The significant value was $0.002<0.05$, with the pre-test mean score 68.5, and the post-test mean score 82.7. Second, the Process Genre Approach was significantly effective to be used to teach writing to extrovert students. The significant value was $0.001<0.05$, with the pre-test mean score 69.4, and the post-test mean score 82.9. Third, the Product Genre Approach was not significantly effective to be used to teach writing to introvert students. The significant value was $0.306>0.05$, with the pre- 
test mean score 66.1 , and the post-test mean score 71.6. Fourth, the Product Genre Approach was significantly effective to be used to teach writing to extrovert students. The significant value was $0.005<0.05$, with the pretest mean score 72.7 , and the post-test mean score 84.2. Fifth, the Process Genre Approach was not significantly more effective to be used to teach writing compared to the Product Genre Approach. The significant value was $0.106>0.05$, with the Process Genre Approach mean score 82.8, and the Product Genre Approach mean score 77.9. Sixth, the students' personalities significantly influenced their writing quality. The significant value was $0.037<0.05$, in which the extrovert played more positive role than the introvert. Seventh, there was a significant interaction between the teaching approaches (Process Genre and Product Genre Approaches) and the students' personalities (introvert and extrovert) on their writing quality. The significant value was $0.043<$ 0.05 . The extrovert students got better results when they were taught by using Product Genre Approach rather than Process Genre Approach; while introvert students got better result when taught using Process Genre Approach rather than Product Genre Approach.

Based on the study results, the researcher suggests English teachers to consider using Process Genre Approach in their writing classes and identify each student's personality in the very beginning of lessons, acknowledging that the students' personalities significantly influence the students' writing quality. Generally, recognizing the students characterictics is needed in order to know what approach that would be suitable to make the students understand well and reach their achievement.

\section{REFERENCES}

Amogne, D. (2013). Enhancing students' writing skills through the genre approach. International Journal of English and Literature, 4(5), 242-248.

Badger, R. and White, G. (2000). A process genre approach to teaching writing.ELT Journal, 54(2), 153-160. 
Brown, H. D. (2000). Principles of Language Learning and Technology. $4^{\text {th }}$ ed. New York: Pearson Education, Inc.

Chen, Y. and Su, S. (2012). A genrebased approach to teaching EFL summary writing.ELT Journal, 66(2), 184-192.

Cohen, L., Manion, L., and Morrison, K. (2007). Research Method in Education. $6^{\text {th }}$ ed. New York: Routledge.

Ellis, R. (1994). The Study of Second Language Acquisition. $2^{\text {nd }}$ ed. Oxford: Oxford University Press.

Graham, S. and Sandmel, K. (2011). The process writing approach: A meta-analysis. The Journal of Educational Research, 104, 396-407.

Ho, B. (2006). Effectiveness of using the process approach to teach writing in 6 Hongkong primary classrooms.Perspectives: Working Papers in English and Communication, 17(1), 1-19.
Mudrika, N. (2011). Skala MBTI. www.nafismudrika.wordpress. com (downloaded on August, $\left.7^{\text {th }} 2013\right)$.

Parks, S., et. al. (2005). "History of Theatre" websites: A brief history of the writing process in a high school ESL language art class. Journal of Second Language Writing, 14, 233258.

Qomarudin, A. (2010).“Correlation between Extraversion Personality and English Writing Skill".A Thesis. Semarang: Diponegoro University.

Sugiyono.(2011). Statistika untuk Penelitian. Bandung: Alfabeta.

Tangpermpoon, T. (2008). Integrated approaches to improve students' writing skills for English major students. $A B A C$ Journal, 28(2), 1-9.

Yang, W. (2012). Evaluating the effectiveness of genre based instruction: A writing course of 
Journal of English Language and Education

Vol 1. No. 1, June 2015

$I S S N$ : 2460-7142

English for hospitality and

tourism. The Asian EFL

Journal, 13(14), 174-193. 


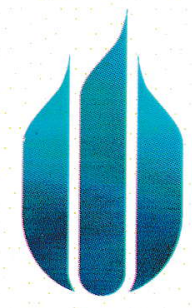

U N I VER S I TAS

MERCU BUANA

Y O G Y A K A R T A

ENGLISH EDUCATION STUDY PROGRAM

Faculty of Teachers Training and Education

Mercu Buana University of Yogyakarta

J. Wates Km. 10 Yogyakarta 55753 | jurnal.umby@gmail.com

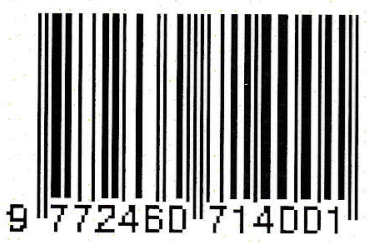

